\title{
Nitrogen-specific uptake rates of marine phytoplankton isolated from natural populations of particles by flow cytometry
}

\author{
Fredric Lipschultz
}

Bermuda Biological Station for Research, Inc., Ferry Reach, GE01, Bermuda

\begin{abstract}
Phytoplankton were isolated from natural heterogeneous populations of particles in Boothbay Harbor, Maine, USA using flow cytometry with cell sorting to measure true rates of nitrogenspecific uptake of ${ }^{15} \mathrm{~N}$ without the bias due to detritus, bacteria or other heterotrophs that affects traditional filtration techniques. After incubation under light or dark conditions with ${ }^{15} \mathrm{NH}_{4}{ }^{+}$or ${ }^{15} \mathrm{NO}_{3}{ }^{-}$, particles were either directly filtered or were sorted to isolate phytoplankton and then filtered for isotopic analysis. Nitrogen-specific $\left(\mu_{\mathrm{N}}\right.$, time $\left.^{-1}\right)$ and absolute uptake rates (mass volume ${ }^{-1}$ time ${ }^{-1}$ ) of ammonium were greater for small $(3-10 \mu \mathrm{m})$ phytoplankton than for larger $(10-53 \mu \mathrm{m})$ phytoplankton, whereas the opposite was observed for uptake of nitrate. Accounting for pronounced diel variations in uptake from both nitrogen sources, algal growth rates were calculated to be $0.38 \mathrm{~d}^{-1}$ on ammonium and $0.05 \mathrm{~d}^{-1}$ on nitrate. The absolute rate of $\mathrm{NH}_{4}{ }^{+}$uptake by all particles as assayed by filtration was approximately balanced by the summed rates of the 2 sorted fractions and the small $(<3 \mu \mathrm{m})$ particles that were removed prior to sorting: phytoplankton represented only $50 \%$ of the total rate. In contrast, phytoplankton uptake of nitrate represented only about one-third of the total uptake, and the remaining fractions contributed only $10 \%$, leaving about $60 \%$ unaccounted for. Future applications of flow cytometry with stable isotopes could be used to investigate diel variations in $\mu_{\mathrm{N}}$ and $\mu_{\mathrm{C}}$ (carbon-specific uptake rates) and provide an estimate of phytoplankton growth rates.
\end{abstract}

KEY WORDS: Flow cytometry Nitrogen Phytoplankton A Assimilation - Growth rates

\section{INTRODUCTION}

Studies of the heterogeneous natural populations of planktonic organisms are hampered by an inability to unambiguously isolate subpopulations for analysis or to express measurements on a unit biomass basis (Sakshaug 1980). Experiments with phytoplankton cultures (Sakshaug \& Holm-Hansen 1977, Goldman et al. 1981) clearly illustrate the potential for large variations in the response of subpopulations to environmental stimuli. Comparable information for field populations is limited however, except under bloom conditions, where a single major species may dominate (e.g. MacIsaac 1978). Competition with phytoplankton for nutrients by bacteria (Laws et al. 1985, Wheeler \& Kirchman 1986, Suttle et al. 1991) can also result in ambiguous or erroneous interpretations when results are attributed solely to phytoplankton. For instance, high rates of ammonium assimilation in the dark (Nelson \& Conway 1979, McCarthy et al. 1982) could be due to bacterial, rather than phytoplankton, activity. The ubiquitous presence of detrital particles in natural samples precludes measurements of biomass-specific rates while the particles themselves act as sites for bacterial activity.

A variety of techniques have been applied to overcome these limitations (Sakshaug 1980). Filtration through sieve filters has frequently been used to isolate subpopulations based on size. Such work has led to the hypothesis that small phytoplankton prefer ammonium whereas large cells primarily use nitrate (Malone 1980, Furnas 1983, Probyn 1985, Koike et al. 1986, Probyn et al. 1990). Size-fractionation has also been used to study the balance between uptake and regeneration of ammonium (Glibert 1982). Although size fractionation may be useful in some cases, it does not provide a clean separation (Taguchi \& Laws 1988, 
Stockner et al. 1990, Lignell 1992). Size is also not always the sole variable required to separate the particle class of interest, as when predators and prey overlap in size or different classes of phytoplankton are present.

Metabolic inhibitors have also been used to remove the influence of a certain type of organism (Sakshaug 1980). Wheeler \& Kirchman (1986), for example, used antibiotics to partition nitrogen assimilation into bacterial and autotrophic components. However, metabolic inhibitors frequently suffer from a lack of specificity or are not completely effective (Itturiaga \& Zsolnay 1981 , Lee et al. 1992).

Physiological rates have often been normalized against a variable that is specific to the appropriate particle type (Sakshaug 1980). Chlorophyll a (chl a) has frequently been used for this purpose in studies of primary productivity and, occasionally, ${ }^{15} \mathrm{~N}$ assimilation (McCarthy ei dl. 1982, Price et al. 1991). However, chlorophyll content per cell can vary widely due to nutrient (Cullen et al. 1983, Banse 1987, Marra et al. 1990) and light history (Cullen et al. 1983, Herman \& Platt 1986) or species composition of the population.

Phytoplankton growth rates $(\mu)$ have been estimated by assuming a constant ratio between chl $a$ and cell carbon and then measuring the rate of incorporation of ${ }^{14} \mathrm{CO}_{2}$ into chlorophyll (Redalje \& Laws 1981, Welschmeyer \& Lorenzen 1984). Redalje \& Laws (1981) utilized the incorporation of ${ }^{14} \mathrm{CO}_{2}$ into protein for the same purpose. Goericke \& Welschmeyer (1993) recently reviewed these methods and concluded that although photoadaptation and diel variations in growth can cause errors, use of diel incubations and a light regime that is consistent with the prior light history of the cells could provide an accurate assessment.

The nitrogen-specific uptake rate $\left(\mu_{N}\right)$, frequently termed $V$ (Dugdale \& Goering 1967), has often been used in studies of phytoplankton nitrogen metabolism to compare the activity of populations from different depths or between diverse ecological regimes (e.g. Macisaac \& Dugdale 1969, Nelson \& Conway 1979, Lebouteiller 1986). However, variations in the relative amounts of phytoplankton and non-phytoplankton material, i.e. more detritus at one depth or station than another, would render any such conclusions invalid. Even changes in $V$ within the same sample over time (Wilkerson \& Dugdale 1987) have been criticized (Garside 1991). The nitrogen-specific uptake rate has also been equated to the growth rate of phytoplankton (Furnas 1983, Probyn 1985, Price et al. 1991), even though the potential errors have been discussed for some time (Eppley 1981).

Automated individual particle analysis and sorting using flow cytometry has the potential to overcome some of these limitations if the technique can be cou- pled to physiological measurements on natural populations (Yentsch et al. 1983, Li 1986, Rivkin et al. 1986). Sorting is automatic, rapid and more than one attribute can be used to identify the particle class of interest. The technique is appropriate for post-incubation, rather than pre-incubation sorting, since flow cytometry affects the health of the phytoplankton (Rivkin et al. 1986). To date, application of flow cytometry to physiological measurements in the ocean have been limited to the use of radioisotopes, specifically ${ }^{14} \mathrm{C}$ (Rivkin et al. 1986, Li 1994). In contrast to measurements with radioisotopes, accumulation of stable isotopes is measured as the change in atom \% abundance or specific activity, thus providing a direct estimate of biomassspecific turnover rates. Stable isotopes have not been used with flow cytometry but such isolation of phytoplankton would permit direct observation of biomassspecific rates of carbon and nitrogon metabolisin.

In the work reported here, I have investigated the use of flow cytometry with cell sorting (FCCS) to isolate the phytoplankton component from the total nitrogen metabolism of the plankton. Measurements of the true nitrogen-specific uptake rate of different size classes of phytoplankton were made over a diel cycle. Uptake of ammonium and nitrate by phytoplankton and by particles without chlorophyll were compared to uptake measured by traditional filtration methods.

\section{MATERIALS AND METHODS}

Experiments were conducted at the Maclsaac Flow Cytometry Facility of the Bigelow Laboratory, Boothbay Harbor, Maine, USA during June 17 to 21, 1990. Seawater samples were collected at dawn from the dock adjacent to the facility and placed in $10 \mathrm{l}$ plastic carboys that were either covered with neutral density screening to achieve a $50 \%$ light level or kept in the dark. Ambient temperatures $\left(11\right.$ to $\left.12^{\circ} \mathrm{C}\right)$ were maintained during the incubations by floating the carboys off the end of the dock. The ambient ammonium concentration on the first day of the experiments was $8 \mu \mathrm{M}$ but dropped to $1.5 \mu \mathrm{M}$ on the second day and remained at that level for the remainder of the experiments. Nitrate levels remained at about $0.1 \mu \mathrm{M}$ over the period.

Early each morning, before beginning an incubation, a sample was analyzed by flow cytometry to identify the major phytoplankton populations using an Epics $\mathrm{V}$ flow cytometer with a $488 \mathrm{~nm}$ argon ion laser operating at $120 \mathrm{~mW}$. Cell size was determined using forward angle light scatter after calibration with a variety of homogeneous size beads. Chlorophyll autofluorescence was used to distinguish phytoplankton from non-chlorophyll-containing particles. A low, constant 


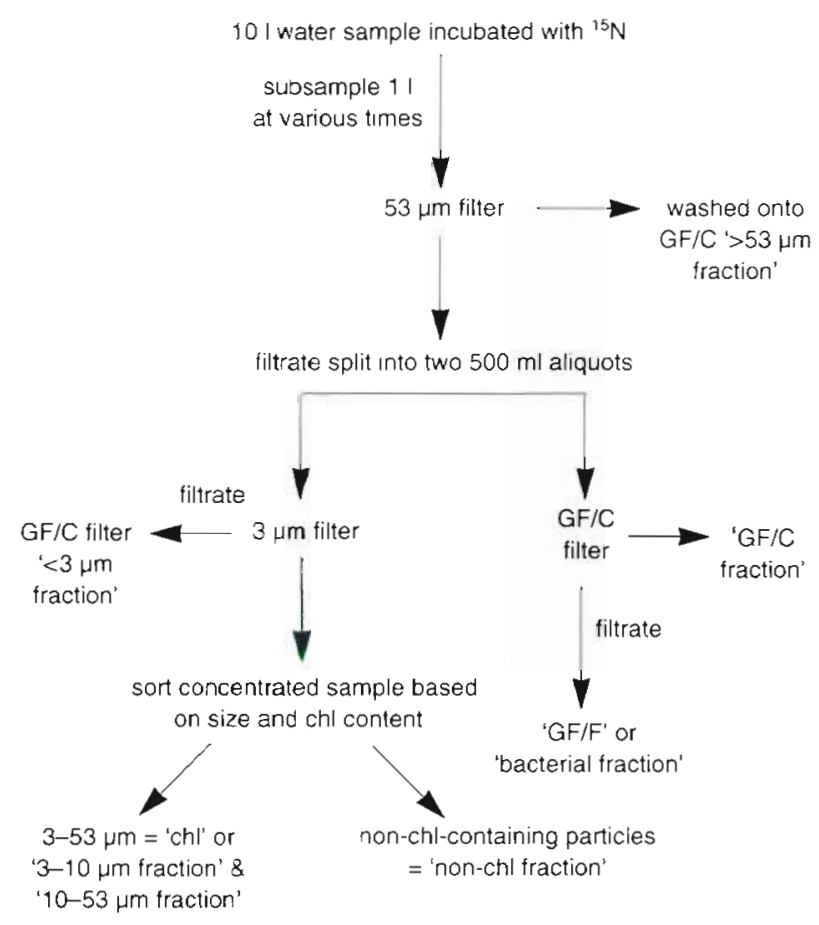

Fig. 1. Experimental protocol for incubation with ${ }^{15} \mathrm{~N}$ and post-incubation separation of the different particle fractions using flow cytometry cell sorting (FCCS)

value of autofluorescence was used for small cells, and a linearly increasing value for cells above $10 \mu \mathrm{m}$ was used to screen for higher background fluorescence as particle size increased. The accuracy of isolating phytoplankton (chlorophyll-containing particles) by FCCS was verified daily by sorting particles directly onto a slide and comparing the number of sorted cells with cells counted by bright field and epifluorescent microscopy. For each experiment, the sort logic was set to isolate 2 different particle types from the ambient population, typically chlorophyll-containing particles (chl) and non-chlorophyll-containing particles (nonchl) or $<10 \mu \mathrm{m}$ and $>10 \mu \mathrm{m}$ chlorophyll-containing particles. The sort gate for the $10 \mu \mathrm{m}$ cutoff was set using $10 \mu \mathrm{m}$ beads.

Incubations were initiated at about 10:00 h with the addition of either $1 \mu \mathrm{M} 99 \%{ }^{15} \mathrm{NH}_{4}{ }^{+}$or ${ }^{15} \mathrm{NO}_{3}{ }^{-}$to the carboys. Subsamples (1 l) were taken at various times and processed to isolate the required fractions (Fig. 1). First, the sample was filtered through a $53 \mu \mathrm{m}$ Nitex screen to remove large particles that might clog the cytometer orifice. The particles were washed off the screen onto a precombusted $\left(450^{\circ} \mathrm{C}\right) \mathrm{GF} / \mathrm{C}$ filter for subsequent isotopic analysis ('>53 $\mu \mathrm{m}$ ' fraction). Then, a $500 \mathrm{ml}$ volume of the filtrate was first passed through a precombusted GF/C filter (1.2 $\mu \mathrm{m}$ nominal pore size) to capture the bulk of the particles ('GF/C' fraction) and then through a precombusted GF/F filter $(0.7 \mu \mathrm{m})$.
This procedure has been used to separate bacteria for biomass studies (Nagata. 1986); hence, the GF/F filter will be considered the 'bacterial' fraction, although it likely contains some autotrophs (Yentsch 1983). The remaining $500 \mathrm{ml}$ of filtrate from the $53 \mu \mathrm{m}$ screening was prepared for FCCS by concentrating the particles over a $3 \mu \mathrm{m}$ Nuclepore filter to a final volume of 2 to $3 \mathrm{ml}$ while maintaining the pressure differential below $25 \mathrm{~mm} \mathrm{Hg}$ to minimize cell breakage. The sample was gently agitated during concentration and, towards the end, the filter was washed with a stream of $0.22 \mu \mathrm{m}$ filtered seawater to prevent clogging. Samples of the filtrate from the $3 \mu \mathrm{m}$ filter (' $<3 \mu \mathrm{m}$ ' fraction) were collected by filtration for isotopic analysis. The remainder of the concentrated sample was then sorted into 2 classes of particles based on the sorting protocol, and the particles were transferred to a precombusted GF/C filter. The concentration and sorting step took about 30 min, rendering the end point of incubation uncertain. Since the concentration step ( $5 \mathrm{~min}$ ) also removed the cells from the ${ }^{15} \mathrm{~N}$ label, the end point for the sorted particles was taken to be $\overline{5}$ min past the termination of the filtered samples.

The isotopic composition of all fractions was determined by emission spectroscopy after optimizing sample preparation to permit analysis of the very small masses of nitrogen that were available from the sorted populations of particles. The filters containing the sorted particles were dried at $70^{\circ} \mathrm{C}$ before being placed on a vacuum system. Sample tubes $(4 \mathrm{~mm}$ inner diameter $\times 15 \mathrm{~mm}$ quartz tubes prefilled with a $\mathrm{CuO} / \mathrm{CaO}$ mixture) were heated to $500^{\circ} \mathrm{C}$ under the vacuum to minimize potential contamination. After cooling, the surface of the glass was degassed with a Tesla coil (Fiedler \& Proksch 1975) and the filters were transferred to the sample tubes (Lipschultz 1984). A $2 \% \mathrm{He} / \mathrm{Xe}$ mixture was added to sustain the emission at the low sample pressures generated from the small mass of particle nitrogen (Goleb \& Middleboe 1968). The sample tubes were then sealed, combusted at $600^{\circ} \mathrm{C}$ for $12 \mathrm{~h}$ and allowed to cool for $24 \mathrm{~h}$ before analysis of the isotopic content of the resulting $\mathrm{N}_{2}$ gas.

An emission spectrometer was built to minimize the sample analysis time of the small samples and to maximize the precision of the isotopic determination (Lipschultz 1993). Even with the He/Xe mixture, the emission intensity slowly declined so that for extremely small samples, the emission lasted only a few seconds. A diode array was therefore used to rapidly record the required spectra without scanning as in conventional instruments. At low sample pressures, weak emissions from higher order vibrational states of the dominant ${ }^{14} \mathrm{~N}:{ }^{14} \mathrm{~N}$ molecule underneath the isotopic bandheads of the ${ }^{15} \mathrm{~N}:{ }^{14} \mathrm{~N}$ molecule artificially increased the apparent isotopic abundance and hence reduced the preci- 
sion of the ratio determination. To correct for this spectral contamination, spectral features surrounding the isotopic bandheads were quantified with standards of differing isotopic composition and sample pressure. Multiple regression analysis yielded a set of coefficients that were applied to the sample spectra, resulting in a highly precise measurement over a wide range of sample pressures.

The nitrogen content of each filtered fraction was measured by CHN analysis (Control Equipment Corp) at the beginning of the experiment. The mass of the sorted particles was also measured by $\mathrm{CHN}$ analysis but several hours of sorting were required to isolate sufficient mass. The nitrogen quota (nitrogen cell-1) of the phytoplankton was then calculated from the mass and number of cells collected during each sort.

Nitrogen contamination during the isotopic analysis was a major concern since only extremely small amounts of nitrogen were available for the sorted particles. Even with a 200-fold concentration of particles on the $3 \mu \mathrm{m}$ filter and sorting for $30 \mathrm{~min}$, only $5 \times$ $10^{-8} \mathrm{~mol}$ of nitrogen was generally available for analysis. The analytical contamination arising during preparation of the sorted particles for isotopic analysis was determined by comparing the isotopic content of large masses of filtered Nannochloris sp. (courtesy of C. Garside) with that of a much smaller mass of sorted cells. The cells were in continuous culture and the culture medium was replaced with one made with ${ }^{15} \mathrm{NO}_{3}{ }^{-}$ rather than ${ }^{14} \mathrm{NO}_{3}{ }^{-}$Cells were then collected from the culture at various times for isotopic analysis. Nannochloris sp. is quite small $(\sim 2 \mu \mathrm{m})$ and sorting $1-2 \times 10^{6}$ cells resulted in $2.5 \times 10^{-8} \mathrm{~mol}$ of nitrogen, comparable to the mass available from the natural samples where about $0.25 \times 10^{6}$ cells in the $3-53 \mu \mathrm{m}$ range were sorted. The measured isotope ratios of the sorted natural particles were corrected using this analytical blank and the mass of sample nitrogen on each filter that was calculated from the previously determined cell quota and the measured number of sorted particles from each time point.

The nitrogen-specific rate $\left(\mu_{N}\right)$ was calculated between each time interval using the equation

$$
\mu_{N}=\frac{\left({ }^{15} N_{S}-n a\right)}{\left({ }^{15} N_{e n t}-{ }^{15} N_{s}\right) \Delta T}=t i m e^{-1}
$$

where na is the natural abundance $(0.366 \%),{ }^{15} \mathrm{~N}_{\text {en }}$ is the isotopic ratio of the labeled source, ${ }^{15} \mathrm{~N}$, is the atom $\%$ abundance of the sample and $\Delta T$ is the time interval between samples. This equation is equivalent to the term $V$ or velocity that is frequently used in the stable isotope literature (Dugdale \& Wilkerson 1986).

To compare the absolute uptake rates $\left(\mu_{\mathrm{N}} \times\right.$ particulate nitrogen concentration) of the sorted particles with that of the GF/C fraction required calculating the particulate nitrogen concentration of all of the particles in the original water sample that met the sort parameters. Although every sorted particle met the sort criteria, the sorting process is slower than the particle flux and hence the instrument does not sort or count every particle that meets the criteria; many pass through in the waste stream. To calculate the nitrogen concentration of the sorted cells, an additional analysis was therefore conducted at the beginning and end of each day to determine the total number of particles in a known volume. A $2 \mathrm{ml}$, unaltered water sample was weighed and then all particles that met the sort criteria were counted without actually sorting the particles. The sample was then reweighed to determine the sorted volume and calculate the particle concentration. The required nitrogen concentration was calculated from the particle concentration and individual cell nitrogen content.

\section{RESULTS}

Most of the experiments took place from June 17 to 21,1991 . Initially the samples contained large numbers of Chaetoceros sp. and Ceratium sp. that were retained on the $>53 \mu \mathrm{m}$ filter. The particulate nitrogen (PN) concentration in that fraction declined 3-fold over the ensuing $5 \mathrm{~d}$ experimental period (Table 1). In contrast, $\mathrm{PN}$ in the $<3 \mu \mathrm{m}$ fraction more than doubled over the period, while $\mathrm{PN}$ in both the GF/C and the GF/F fractions remained constant. The molar $\mathrm{C}: \mathrm{N}$ ratio remain-ed quite constant at between 5 and 7 for these filtered fractions. The sorted phytoplankton population $(3-53 \mu \mathrm{m})$ was dominated by individual cells of 


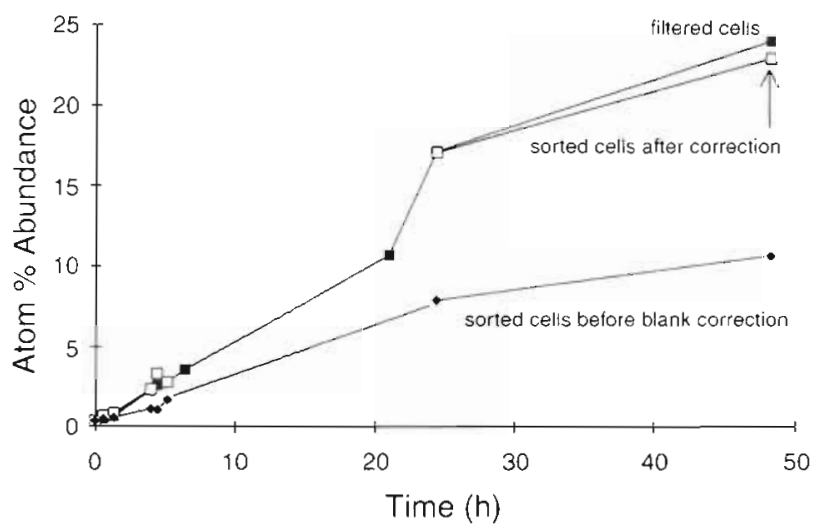

Fig. 2. Incorporation of ${ }^{15} \mathrm{NO}_{3}{ }^{-}$by Nannochloris sp in continuous culture. Cells were either filtered onto GF/C filters or sorted from the cell culture by FCCS before filtration. The isotopic composition of the sorted cells was corrected for the dilution due to analytical contamination (see 'Materials and methods')

Chaetoceros sp., Leptocylindrus sp. and Thallasiosira sp. (E. Haugin pers, comm.) and increased from $24 \%$ of the total particles to $68 \%$ over the $5 \mathrm{~d}$. The $\mathrm{C}: \mathrm{N}$ of the sorted cells was also between 5 and 7 , and the cell quota averaged $1.7 \times 10^{-13} \mathrm{~mol} \mathrm{~N}$ cell ${ }^{-1}$ for the entire 3-53 $\mu \mathrm{m}$ fraction. Cells larger than $10 \mu \mathrm{m}$ had a higher cell $\mathrm{N}$ quota of $7.5 \times 10^{-13} \mathrm{~mol}$. There were approximately $5.8 \times 10^{3}$ phytoplankton cells $\mathrm{ml}^{-1}\left(1.2 \times 10^{3}\right.$ standard deviation) in the water during this period. No consistent pattern was observed in any of these parameters during the individual incubations

Correcting the measured isotope ratio of the sorted cells for the dilution caused by the analytical blank was quite effective. After correction, the atom \% abundance of the small mass of sorted Nannochloris sp. compared extremely well with that of the much larger mass of filtered cells (Fig. 2). The efficacy of the correction for a field population was tested by measuring the isotopic composition of $0.5 \times 10^{5}, 1.0 \times 10^{5}$ and $2.0 \times 10^{5}$ cells sorted from a single sample. Due to the variable sample mass and presumably constant analytical blank, the measured isotopic content of the cells initially varied by $50 \%$; but, after the correction, the coefficient of variation was reduced to $7.7 \%$, indicating that the contaminating blank was reasonably constant. For unknown reasons, the analytical blank of the sorted cells $\left(3 \times 10^{-8}\right.$ $\mathrm{mol} \mathrm{N}$ ) was considerably higher than the $0.5 \times 10^{-8}$ blank measured from just a combusted filter.

\section{Ammonium uptake}

Phytoplankton incubated in the light had a higher isotopic abundance than the GF/C fraction (Figs. 3
\& 4), as would be expected since the nonliving nitrogen component, present in filtered samples, was removed. The label entered all fractions at a generally constant rate during the light period, but slowed overnight in the GF/C and chl fractions containing autotrophs (Fig 3A). In one experiment (Fig. 4), the sort protocol was inadvertently set to isolate only the 3-10 $\mu \mathrm{m}$ cells rather than the full 3-53 $\mu \mathrm{m}$ range. Upon discovering this during the incubation, the sort logic was altered to ignore non-chlorophyll-containing particles and to differentiate between the small (3-10 $\mu \mathrm{m})$ and large $(10-53 \mu \mathrm{m})$ phytoplankton. Small cells acquired ${ }^{15} \mathrm{NH}_{4}{ }^{+}$at twice the rate of the larger cells (Fig. 4A). The smallest and the largest
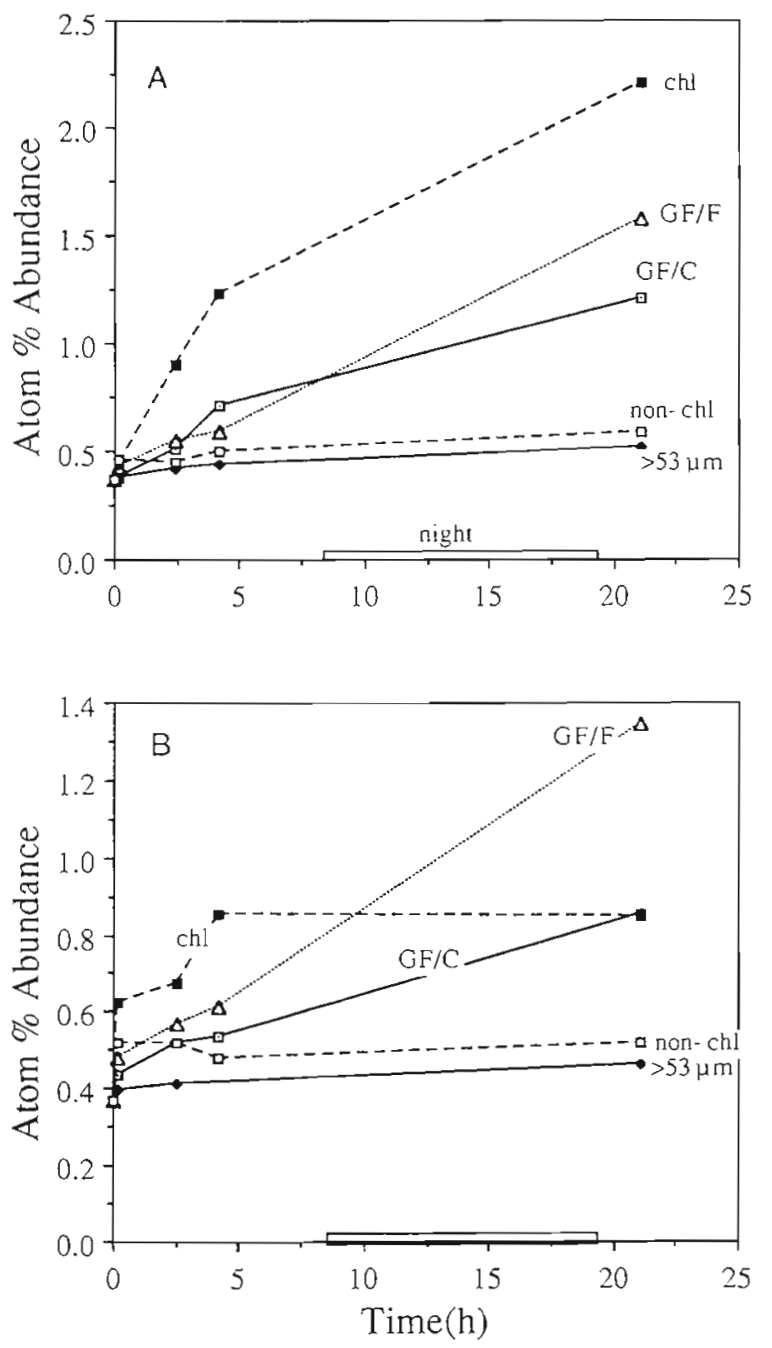

Fig. 3. Diel time course of ${ }^{15} \mathrm{NH}_{4}{ }^{+}$uptake into natural populations of phytoplankton isolated by FCCS and into heterogeneous populations of particles separated by filtration. Populations were incubated (A) at $50 \%$ ambient light level and (B) in the dark (note scale change). See 'Materials and methods' for explanation of fractions 
filtered fractions, which include detritus, had the lowest isotopic values of the phytoplankton-containing fractions and were similar to the non-chlorophyll particles.

All fractions containing phytoplankton accumulated ${ }^{15} \mathrm{NH}_{4}{ }^{+}$at a rate much reduced in the dark as compared to the light (Figs. 3B \& 4B). However, particles that passed the GF/C filter and were captured on the GF/F filter ('bacteria') took up the same amount of label in the dark as in the light, resulting in a higher ratio than all the other particles types had in the dark. The non-chlorophyll-containing particles consistently had the lowest isotopic ratio, reflecting a low amount of living biomass compared to detritus.
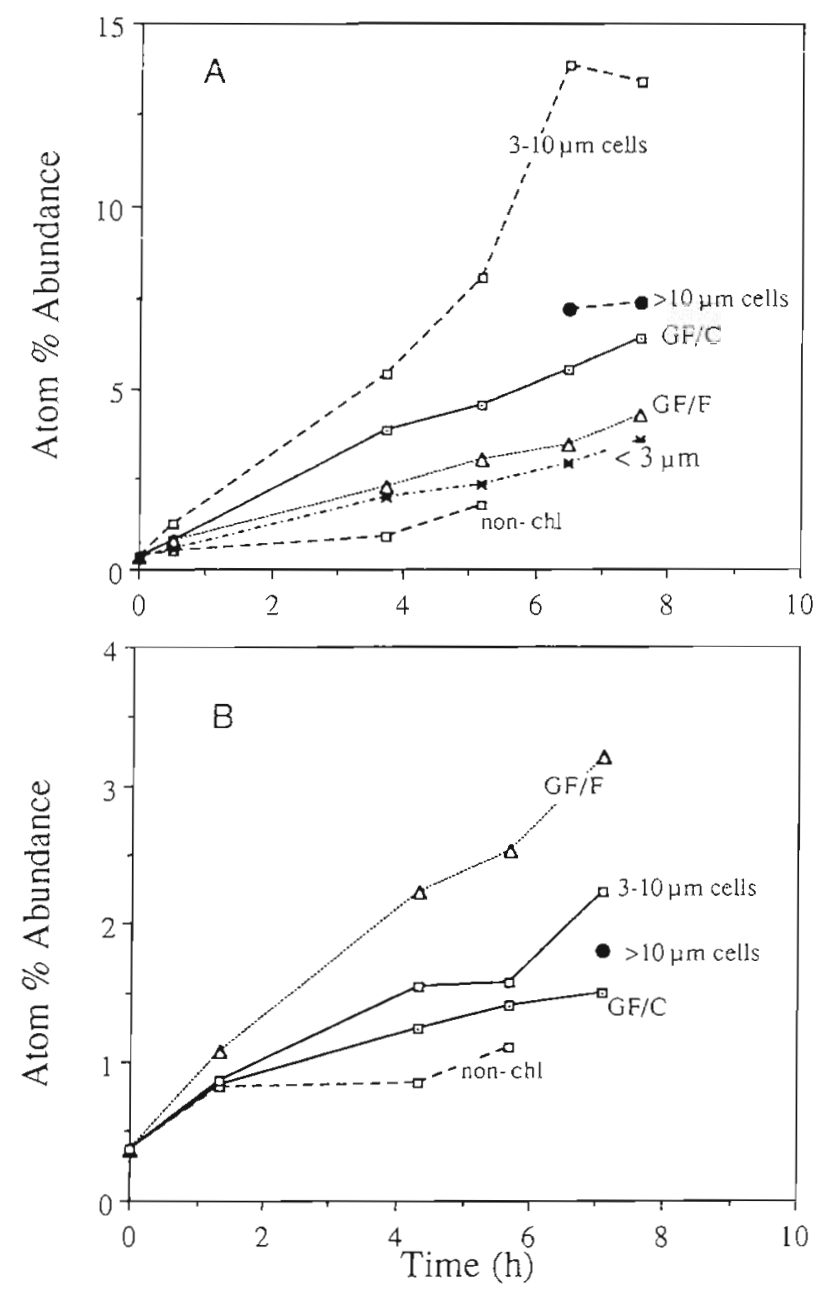

Fig. 4. Time course of ${ }^{15} \mathrm{NH}_{4}{ }^{+}$uptake into different size classes of natural populations of phytoplankton isolated by FCCS and into heterogeneous populations of particles separated by filtration. Populations were incubated (A) at $50 \%$ ambient light level and (B) in the dark (note scale change). See 'Materials and methods' for explanation of fractions
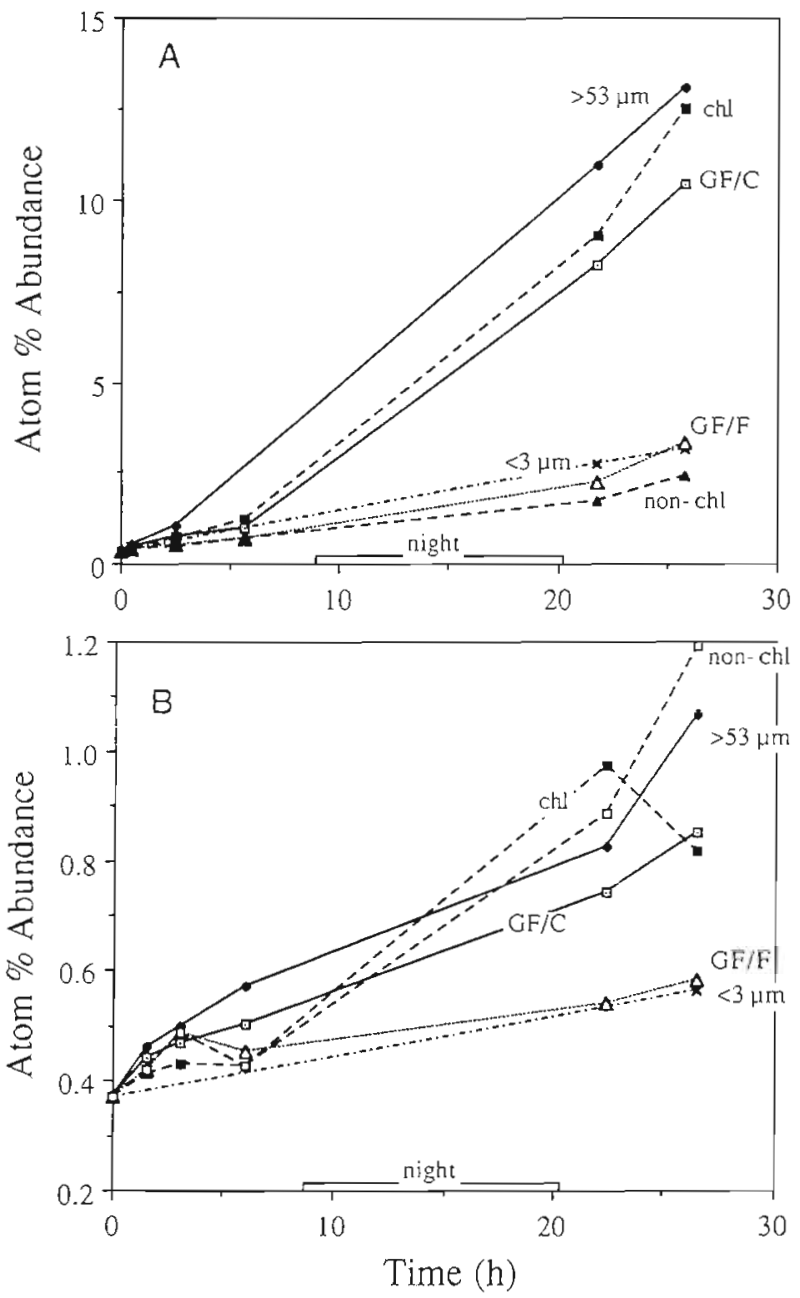

Fig. 5. Time course of ${ }^{15} \mathrm{NO}_{3}{ }^{-}$uptake into different size classes of natural populations of phytoplankton isolated by FCCS and into heterogeneous populations of particles separated by filtration. Populations were incubated (A) at $50 \%$ ambient light level and (B) in the dark (note scale change). See 'Materials and methods' for explanation of fractions

\section{Nitrate uptake}

In both experiments with ${ }^{15} \mathrm{NO}_{3}{ }^{-}$, the isotopic composition of the sorted cells and the GF/C fraction increased at a similar rate and reached a similar degree of labeling even though the GF/C fraction included detritus (Figs. $5 \& 6$ ). The $>53 \mu \mathrm{m}$ particles had a much higher isotopic ratio than the $<3 \mu \mathrm{m}$ particles, again in contrast to uptake of ammonium. Large phytoplankton acquired label faster than the smaller $(3-10 \mu \mathrm{m})$ cells (Fig. 6A) during the light incubation; the opposite pattern to uptake of ${ }^{15} \mathrm{NH}_{4}{ }^{+}$(Fig. 4A). Phytoplankton continued to accumulate ${ }^{15} \mathrm{NO}_{3}{ }^{-}$in the dark, regardless of the size of the cells (Figs. $5 \mathrm{~B} \& 6 \mathrm{~A}, \mathrm{~B}$ ).

The GF/F fraction took up very little label in either the light or the dark, especially compared to the incu- 

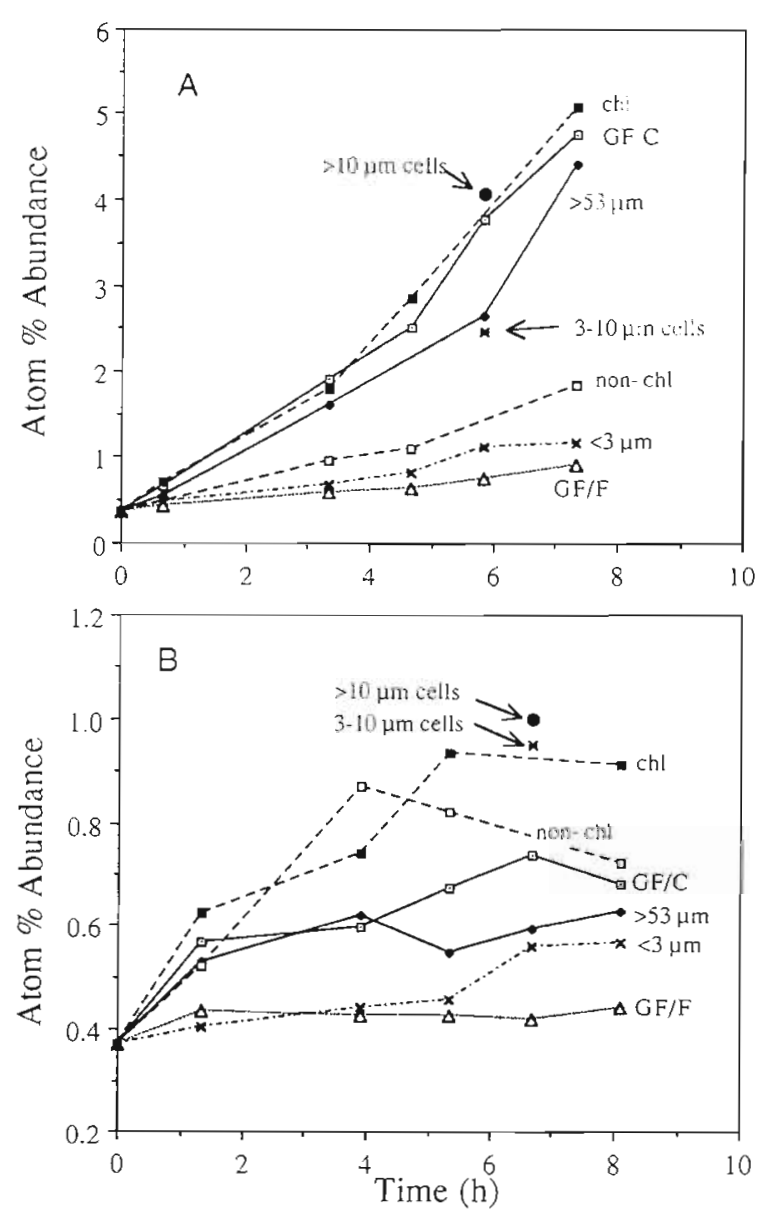

Fig. 6. Time course of ${ }^{15} \mathrm{NO}_{3}^{-}$uptake into different size classes of natural populations of phytoplankton isolated by FCCS and into heterogeneous populations of particles separated by filtration. Populations were incubated $(A)$ at $50 \%$ ambient light level and (B) in the dark (note scale change). See 'Materials and methods' for explanation of fractions

bation with ${ }^{15} \mathrm{NH}_{4}{ }^{+}$. Interestingly, the non-chlorophyllcontaining particles became more highly labeled than the GF/F fraction in both the light and the dark, again in contrast to uptake of $\mathrm{NH}_{4}{ }^{+}$.

A very different pattern was observed during 2 experiments with ${ }^{15} \mathrm{NO}_{3}{ }^{-}$in late March (Fig. 7). The tracer initially accumulated rapidly in the phytoplankton $(3-53 \mu \mathrm{m})$ incubated at $5 \%$ of the surface light intensity but then the isotopic composition dramatically declined (Fig. 7A). A similar pattern was observed in the large particles $(>53 \mu \mathrm{m})$ and the GF/F fraction but not in the particles trapped on the GF/C filter. The decline in isotopic composition of the sorted cells also occurred during incubation under $50 \%$ light intensity (Fig. 7B), but the decline was much reduced in the $>53 \mu \mathrm{m}$ fraction and missing from the GF/F fraction. A decline in isotopic ratio during uptake of ${ }^{15} \mathrm{NO}_{3}{ }^{-}$was also ob-
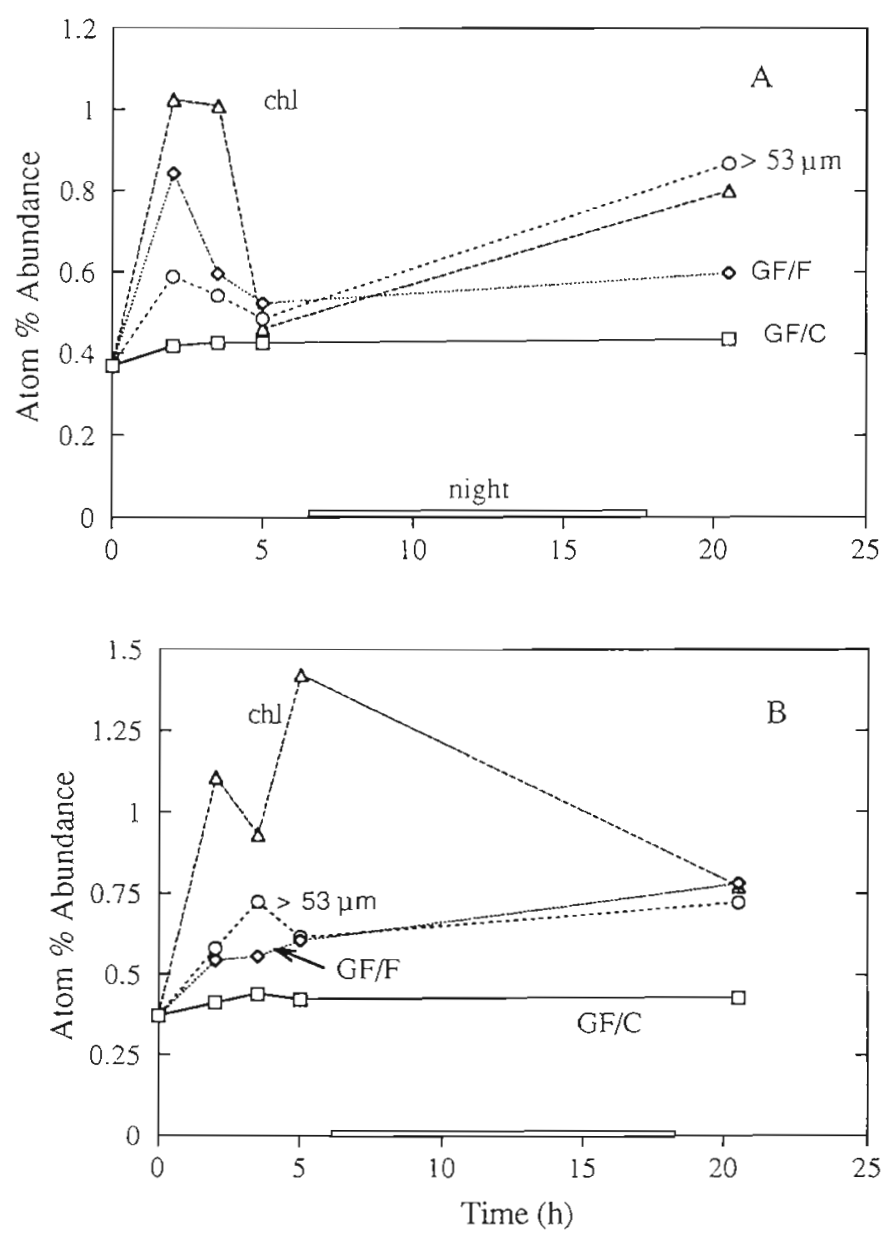

Fig. 7 Time course of ${ }^{15} \mathrm{NO}_{3}{ }^{-}$uptake in Apri]. Different size classes of natural populations of phytoplankton isolated by FCCS and various heterogeneous populations of particles were separated by filtration. Populations were incubated (A) at $5 \%$ ambient light level and (B) at $50 \%$ ambient light. See 'Materials and methods' for explanation of fractions

served in a culture of Dunaliella tertiolecta (Fig. 8). Both filtered and sorted cells accumulated ${ }^{15} \mathrm{~N}$ during the initial hours of exposure to the label but then the atom $\%$ abundance dropped sharply. The decline was not due to loss of internal stocks of ${ }^{15} \mathrm{NO}_{3}{ }^{-}$or of low molecular weight compounds since the decline was also observed in cells treated with cold trichloroacetic acid (TCA) to precipitate macromolecules.

Nitrogen-specific rates $\left(\mu_{N}\right)$ were higher in the light than the dark for both ammonium and nitrate (Table 2 ). In the light, ammonium uptake was $0.0192 \mathrm{~h}^{-1}$ for the 3-53 $\mu \mathrm{m}$ size cells, much greater than nitrate uptake measured on the next day $\left(0.0017 \mathrm{~h}^{-1}\right)$. Similarly, on the last day, ammonium was assimilated at $0.037 \mathrm{~h}^{-1}$ while on the previous day, nitrate was assimilated at only $0.0042 \mathrm{~h}^{-1}$ for the same $3-10 \mu \mathrm{m}$ size class. As indicated before (Figs. $4 \mathrm{~A} \& 6 \mathrm{~A}$ ), $\mu_{\mathrm{N}}$ with $\mathrm{NH}_{4}{ }^{+}$was 

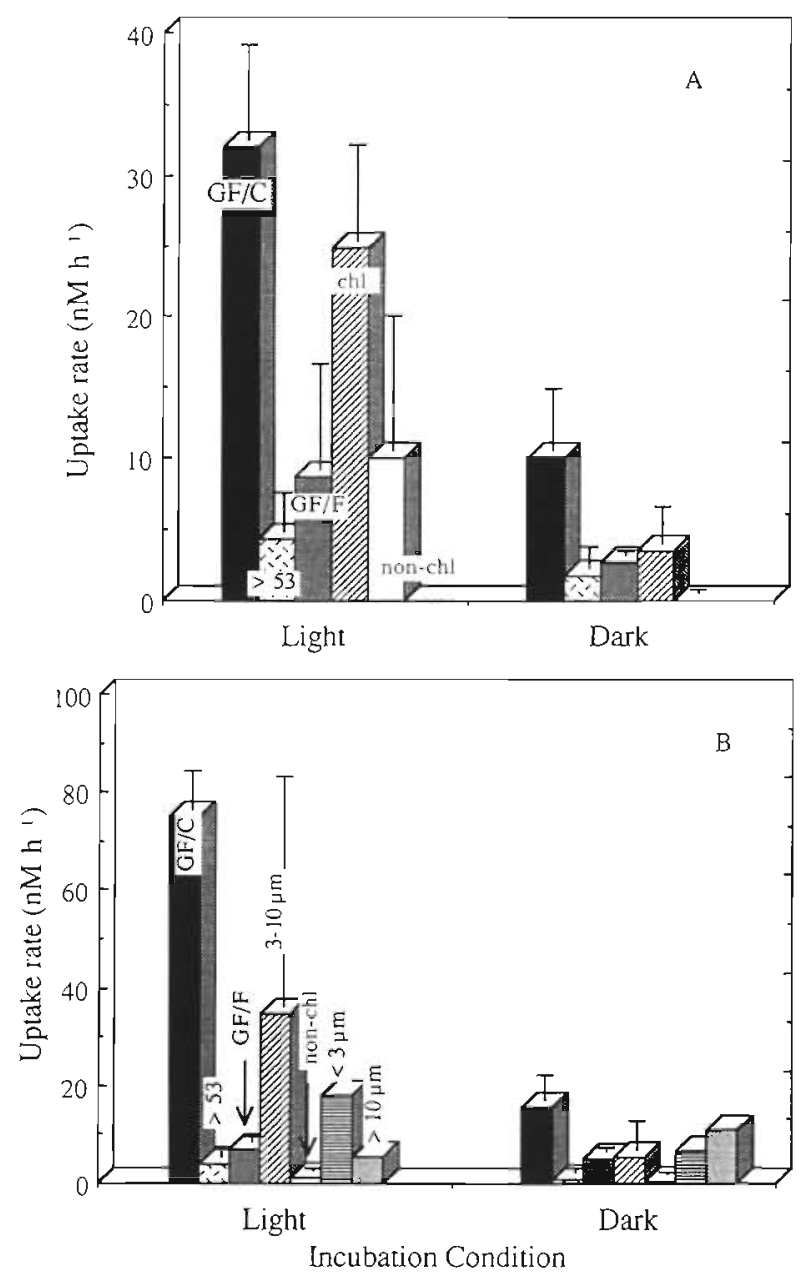

Fig. 9. Comparison of the absolute uptake rates of ${ }^{15} \mathrm{NH}_{4}{ }^{+}$on (A) June 17 and (B) June 21 by the different fractions for the experiments shown in Figs. 3 \& 4. Values are the mean rate over the individual time intervals. Error bars are the standard error of the means. See 'Materials and methods' for explanation of fractions

the large sorted cells with higher $\mu_{\mathrm{N}}$ for nitrate than for ammonium. The $<3 \mu \mathrm{m}$ fraction actually had a comparable isotopic composition regardless of the nitrogen source (cf. Figs. 4A \& 5A) and never reached the degree of labeling of the slightly larger 3-10 $\mu \mathrm{m}$ phytoplankton. Any interpretation of $\mu_{\mathrm{N}}$ for this fraction, however, would be questionable, even between the different days of the incubation, because the low atom \% abundance is evidence for a large amount of detritus. The living component was likely to have been growing quite rapidly since the absolute flux was comparable to that of the sorted cells. Although this is a limited set of data, it illustrates the utility of FCCS in overcoming the methodological bias of earlier efforts and provides support for the concept of preferential use of ammonium by smaller cells.
Given the interest in the relative role of bacteria compared to phytoplankton in nitrogen cycling, it is worthwhile to crudely estimate the extent of bacterial influence on the traditional filtration assessment of nitrogen uptake. I deliberately used a GF/C filter to remove the bulk of the particles in a size range closer to the limit of the flow cytometer but also to pass most of the bacteria (Nagata 1986). Particles retained by subsequent filtration through a GF/F filter would have had a greatly enhanced proportion of bacteria relative to phytoplankton, although some phytoplankton do pass a GF/C (Yentsch 1983). However, the lack of a strong light response by the GF/F fraction as compared to the phytoplankton containing fractions (chl and GF/C) lends support to viewing this fraction as primarily bacterial (Fig. 9). Attached bacteria might also be responsible for a portion of the uptake of nitrogen by
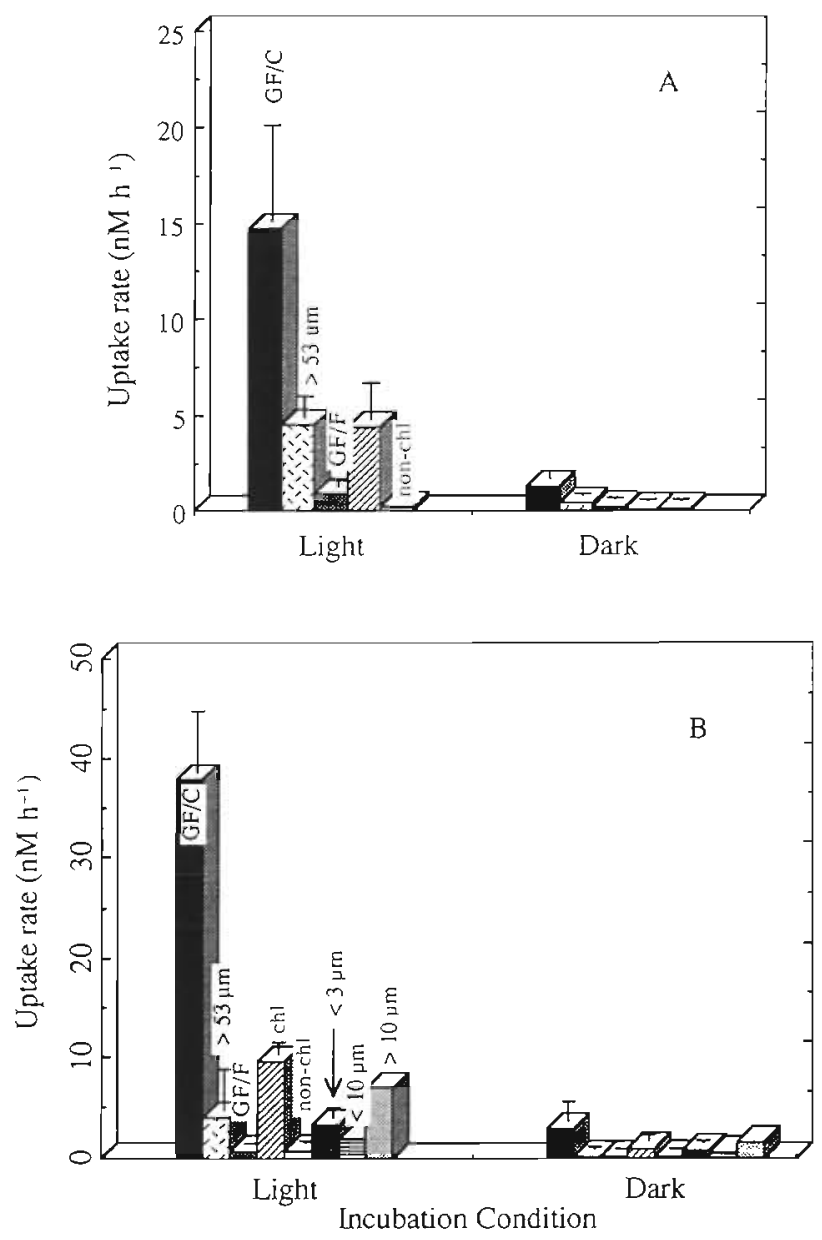

Fig. 10. Comparison of the absolute uptake rates of ${ }^{15} \mathrm{NO}_{3}{ }^{-}$on (A) June 18 and (B) June 20 by the different fractions for the experiments shown in Figs. $5 \& 6$. Values are the mean rate over the individual time intervals. Error bars are the standard error of the means. See 'Materials and methods' for explanation of fractions 
the non-chlorophyll-containing particles (Fig. 9A). Comparing the rates for the GF/F and non-chlorophyllcontaining particles to the rate for all particles (GF/C and GF/F) on a diel basis, bacteria accounted for $34 \%$ of total ammonium uptake at the beginning of the experiments, declining to $18 \% 4 \mathrm{~d}$ later. Clearly this adds to the accumulating body of evidence suggesting significant bacterial competition for nutrients (Wheeler \& Kirchman 1986).

Bacteria are generally not thought to compete with phytoplankton for nitrate (Wheeler \& Kirchman 1986) although Horrigan et al. (1984) have reported consumption of nitrate in seawater cultures of natural bacteria. Uptake of nitrate was observed in both the 'bacterial' and the non-chl fractions but to a much lower extent than that in the phytoplankton (Fig. 10). As noted above, this observation should be interpreted with some caution since small autotrophs may have passed the GF/C filter and been trapped on the GF/F filter. Similarly, the non-chlorophyll-containing particles might include moribund phytoplankton that were still capable of assimilation of nutrients. Given these raveats, nitrate uptake by the non-chlorophyll-containing particles and 'bacterial' fraction averaged only $10 \%$ of the total nitrate uptake measured by the filtered fractions.

\section{Nitrogen-specific uptake}

A major objective of this research was to use FCCS to more accurately measure the nitrogen-specific uptake rate $\left(\mu_{\mathrm{N}}\right)$ and, since nitrogen is a substantial component of all cells, $\mu_{\mathrm{N}}$ could be used to estimate the phytoplankton growth rate $(\mu)$. Conceptually, this approach is similar to measuring $\mu$ using the ${ }^{14} \mathrm{C}$ labelling of pigments (Redalje \& Laws 1981, Welschmeyer \& Lorenzen 1984, Gieskes \& Kraay 1989), where measuring the specific activity of algal pigments removes the interference from detrital and bacterial components of the particle population. The change in specific activity of algal. pigments with time $\left(\mu_{\mathrm{chl}}\right)$ is assumed to closely follow the growth of the entire cell.

However, during a short-term experiment, $\mu_{N}, \mu_{\mathrm{chl}}$ or any other cell constituent will only equal $\mu$ when a population is growing under conditions of balanced growth, i.e. when all cell constituents are increasing at the same rate (Burmaster 1979, Eppley 1981, Morel 1987). Since natural populations are rarely in a state of balanced growth due to variations in photosynthesis over the diel light cycle and in response to changing nutrient conditions, equating $\mu$ to $\mu_{\mathrm{N}}$ is fraught with problems (Furnas 1990, Eppley 1981). For instance, assimilation of nitrogen and protein synthesis can continue at night at the expense of carbon fixed during the day (Laws \& Wong 1978, Cuhel et al. 1984) or, under nutrient replete conditions, growth may cease during the night as was observed by Ditullio \& Laws (1983) using ${ }^{14} \mathrm{CO}_{2}$ incorporation into protein to measure nitrogen assimilation. Nitrogen can also be taken up in excess of immediate cellular demand ('surge' uptake) if concentrations are suddenly increased (Goldman et al. 1981, Wheeler et al. 1982). Recently, similar problems have been observed with the ${ }^{14} \mathrm{C}$-chl labelling technique (Goericke \& Welschmeyer 1993).

However measurements of the biomass-specific rates can closely approximate $\mu$ if the measurement period is extended to include both the light and dark cycle and the ambient environment is not perturbed (Eppley 1981, Goericke \& Welschmeyer 1993). There was no evidence for surge uptake as the label incorporation was linear (Figs. 3 to 6) and ambient environmental conditions were maintained during the incubations so that $\mu_{\mathrm{N}}$ should provide a robust estimate of $\mu$. Growth rates were estimated based on a 12:12 h day using linear regressions of the uptake curves (Figs. 3 to 6) to calculate $\mu_{\mathrm{N}}$ under both light and dark conditions (Table 2).

Since both ammonium and nitrate were available as nitrogen sources for growth, the rates for each were summed to estimate the total daily growth rate (Lund 1987, Collos 1989). I also averaged the rates for each nutrient, even though the 4 experiments were conducted over $5 \mathrm{~d}$, with either ${ }^{15} \mathrm{NH}_{4}{ }^{+}$or ${ }^{15} \mathrm{NO}_{3}{ }^{-}$used on a given day. Since grazing would not affect the estimates, the rates should be considered gross rather than net rates of cell increase. The community growth rate for the week was calculated as $0.43 \mathrm{~d}^{-1}$, with growth on ammonium accounting for $0.38 \mathrm{~d}^{-1}$ and nitrate for $0.05 \mathrm{~d}^{-1}$ (Table 2). The rate for the $3-10 \mu \mathrm{m}$ phytoplankton was about twice that of the larger cells $\left(0.55 \mathrm{~d}^{-1}\right.$ vs $\left.0.34 \mathrm{~d}^{-1}\right)$ These growth rate estimates could be somewhat low since they do not include uptake of additional sources of nitrogen such as urea. Excretion of recently fixed dissolved organic nitrogen (DON) does not contribute to cell growth and hence would not affect these estimates (Bronk \& Glibert 1993a, b).

The rates estimated here for temperate coastal water are certainly within the broad range of values reported for other temperate coastal waters using a variety of other techniques (Furnas 1990). The stable isotope rate determined using ${ }^{15} \mathrm{~N}$ is quite comparable to the value of about $0.5 \mathrm{~d}^{-1}$ reported by Chang \& Carpenter (1991) for a nearby temperate coastal site using a method based on direct observation of phytoplankton DNA that is also free from detrital and bacterial influence.

Using FCCS, I was also able to make the first measurement of the C:N ratio of phytoplankton without interference from extraneous particles. As phytoplank- 
ton growing in cultures approach $\mu_{\max }$ their C:N ratio declines to approximately 6 , a value comparable to that observed in natural populations of particles, suggesting that phytoplankton are frequently growing at near-maximal rates (Goldman et al. 1979). An average value of 6.2 for the $3-53 \mu \mathrm{m}$ cells is evidence that the natural population in Boothbay Harbor was growing rapidly.

The accumulation of ammonium in the phytoplankton was greatly diminished at night (Fig. $3 \mathrm{~A}$ ) or in the dark (Figs. 3B \& 4B). In contrast, the bacterial fractions continued to take up ammonium regardless of the light. However, uptake by the GF/C fraction in the dark is a significant fraction of uptake in the light (Fig. 9A, B), a result frequently found for natural populations (MacIsaac \& Dugdale 1972, Nelson \& Conway 1979. Lipschultz et al. 1985). Clearly, the bacteria are a significant factor and care must be taken in designing experiments to include their contribution as part of the plankton or to exclude them for consideration of phytoplankton dynamics.

Although linear accumulation of label was observed during all experiments in June, experiments with ${ }^{15} \mathrm{NO}_{3}{ }^{-}$in early April were strikingly different (Figs. 7 \& 8). A drastic decrease was observed in the isotopic composition of the sorted cells, the $>53 \mu \mathrm{m}$ filtered fraction and the GF/F or 'bacterial' fractions in the low light incubation, with a similar but less pronounced pattern in the high light incubation. The same phenomenon was observed in an experiment with a culture of Dunaliella tertiolecta (Fig. 8). The decline in isotopic composition could be due to several factors. Isotope dilution of the ${ }^{15} \mathrm{~N}$ enriched substrate $\left(\mathrm{N}_{\mathrm{ent}}\right)$ by remineralization $\left(\mathrm{NH}_{4}{ }^{+}\right)$or nitrification $\left(\mathrm{NO}_{3}{ }^{-}\right)$would cause $\mathrm{N}_{\mathrm{enr}}$ to decline below the isotopic composition of the samples $\left(N_{s}\right)$, causing $N_{s}$ to eventually decline. Although $N_{\text {enr }}$ was not measured, the nutrient concentrations did not change during the incubation, and less than $20 \%$ of the nitrogen source was assimilated so that the dilution could not have diluted $N_{\text {en }}$ below $N_{s}$. Phytoplankton might excrete $\mathrm{NO}_{3}{ }^{-}$taken up early in the incubation as $\mathrm{NO}_{2}^{-}$(Olson et al. 1980, French et al. 1983); however, the experiment with cultured algae showed the effect in the macromolecular fraction as well as the live cells, indicating the effect included assimilation rather than solely uptake. Switching from assimilation of ${ }^{15} \mathrm{NO}_{3}{ }^{-}$to assimilation of another, unlabeled, nitrogen source such as $\mathrm{NH}_{4}{ }^{+}$or urea would dilute the existing label, although it is difficult to conceive why this would occur so dramatically in the middle of the day (Fig. 7) or especially in the culture (Fig. 8). Excretion of freshly assimilated and hence highly labeled DON (Bronk \& Glibert 1993a, 1993b) at certain times of the day would also decrease the isotopic composition of the remaining cellular material.
The initial rise in isotopic composition would then reflect the low molecular weight compounds being synthesized and the decline would reflect excretion of these compounds. Any of these pathways could be invoked to explain observed imbalances between assimilation of ${ }^{15} \mathrm{~N}$ and changes in concentration (Dugdale \& Wilkerson 1986, Ward et al. 1989, Lipschultz 1994). It is likely no coincidence that the decrease was only observed for nitrate, not for ammonium, and that the imbalance is greater for nitrate than for ammonium.

\section{Filter-fractionation and sorting}

Absolute rates of nitrogen uptake by the 2 sorted fractions should approach the amount taken up by the heterogeneous particles sampled by the GF/C filter. An accurate comparison with the GF/C filter however requires summing not only the sorted fractions, but also the $<3 \mu \mathrm{m}$ particles that were removed during preconcentration of the samples for FCCS. Summing rates for the phytoplankton, the non-chlorophyllcontaining particles and the $<3 \mu \mathrm{m}$ fraction for the experiment where the $<3 \mu \mathrm{m}$ fraction was measured (Fig. 9B), net assimilation of $\mathrm{NH}_{4}{ }^{+}$was $79 \%$ of the GF/C filter for the light and $152 \%$ for the dark incubation (Table 3 ). Although the $<3 \mu \mathrm{m}$ fraction was not measured during the other experiment with ${ }^{15} \mathrm{NH}_{4}{ }^{+}$ (Fig. 9A), its contribution is likely to be small because the $\mathrm{PN}$ in that fraction was 3-fold lower than in the later experiment. The combined uptake by the 2 sorted particle classes in that experiment accounted for $109 \%$ and $36 \%$ of the GF/C fraction in the light and dark respectively (Table 3 ). In general, the agreement between the FCCS technique and traditional filtration for both experiments with $\mathrm{NH}_{4}{ }^{+}$was reasonable for this first attempt to use FCCS in such a quantitative comparison of nitrogen uptake.

Uptake of ${ }^{15} \mathrm{NO}_{3}{ }^{-}$into the aggregated fractions in both of the experiments ranged from 11 to $63 \%$ of that of the GF/C filter in both light and dark treatments (Fig. 10). In these experiments, the phytoplankton component alone should have closely approximated the total particle load since the $<3 \mu \mathrm{m}$ fraction and the non-chl particles that contributed heavily to the net uptake of $\mathrm{NH}_{4}{ }^{+}$ did not take up substantial amounts of $\mathrm{NO}_{3}{ }^{-}$. One clear difference from the results with $\mathrm{NH}_{4}{ }^{+}$was that isotopic composition of the phytoplankton in both ${ }^{15} \mathrm{NO}_{3}{ }^{-}$experiments was close to that of the particles on the GF/C filters (Figs. 5A \& 6A), rather than much higher, as would be expected since removal of nonliving particles would increase the isotopic ratio of the remaining nitrogen. This result is especially puzzling since the phytoplankton represented only $50 \%$ of the total particle load on both days. 
Table 3. Comparison of absolute uptake rates ( $\mathrm{nM} \mathrm{N} \mathrm{h}{ }^{-1}$ ) based on FCCS (see 'Materials and methods') and on filtration. Chl: $3-53 \mu \mathrm{m}$ chlorophyll-containing partıcles; $>10 \mu \mathrm{m}:>10 \mu \mathrm{m}$ chlorophyll-containing particles; non-chl: $3-53 \mu \mathrm{m}$ particles without chlorophyll fluorescence; $<3 \mu \mathrm{m}$ : particles passed a $3 \mu \mathrm{m}$ Nuclepore filter but retained on a GF/F filter; $G F / C$ : all particles retained on a GF/C filter. The aggregate value is the sum of the sorted fractions and the $<3 \mu \mathrm{m}$ fraction

\begin{tabular}{|c|c|c|c|c|c|c|c|c|}
\hline & & $G F / C$ & Chl & $>10 \mu \mathrm{m}$ & non-chl & $<3 \mu \mathrm{m}$ & Aggregate & $\begin{array}{l}\text { Aggregate: } \\
\text { GF/C }(\%)\end{array}$ \\
\hline $\begin{array}{l}\mathrm{NH}_{4}{ }^{\circ} \\
\text { June } 17\end{array}$ & $\begin{array}{l}\text { Light } \\
\text { Dark }\end{array}$ & $\begin{array}{l}32 \\
10\end{array}$ & $\begin{array}{r}24.8 \\
3.6\end{array}$ & & $\begin{array}{l}9.97 \\
0\end{array}$ & & $\begin{array}{r}34.8 \\
3.6\end{array}$ & $\begin{array}{r}109 \\
36\end{array}$ \\
\hline June 21 & $\begin{array}{l}\text { Light } \\
\text { Dark }\end{array}$ & $\begin{array}{l}75 \\
15.5\end{array}$ & $\begin{array}{r}34.6^{\mathrm{d}} \\
5.3^{\mathrm{d}}\end{array}$ & $\begin{array}{l}5.5 \\
11\end{array}$ & $\begin{array}{l}1.0 \\
0.5\end{array}$ & $\begin{array}{c}18 . \\
6.8\end{array}$ & $\begin{array}{l}59.1 \\
23.6\end{array}$ & $\begin{array}{r}79 \\
152\end{array}$ \\
\hline $\begin{array}{l}\mathrm{NO}_{3}^{-} \\
\text {June } 18\end{array}$ & $\begin{array}{l}\text { Light } \\
\text { Dark }\end{array}$ & $\begin{array}{r}14.7 \\
1.3\end{array}$ & $\begin{array}{l}4.4 \\
0.10\end{array}$ & & $\begin{array}{l}0.24 \\
0.13\end{array}$ & & $\begin{array}{l}4.6 \\
0.1\end{array}$ & $\begin{array}{l}32 \\
11\end{array}$ \\
\hline June 20 & $\begin{array}{l}\text { Light } \\
\text { Dark }\end{array}$ & $\begin{array}{l}38 \\
2.9\end{array}$ & $\begin{array}{l}9.5 \\
1.03\end{array}$ & & $\begin{array}{l}0.7 \\
0.11\end{array}$ & $\begin{array}{l}3.3 \\
0.7\end{array}$ & $\begin{array}{r}13.5 \\
1.8\end{array}$ & $\begin{array}{l}36 \\
63\end{array}$ \\
\hline
\end{tabular}

Several factors might affect the accuracy of the FCCS based estimates of $\mu_{N}$ and uptake. Accurate evaluation of the nitrogen content of the sorted particles and the analytical contamination are required. The cell quota of $1.7 \times 10^{-13} \mathrm{~mol} \mathrm{~N}$ cell ${ }^{-1}$ for the $3-53 \mu \mathrm{m}$ cells and $7.5 \times$ $10^{-13}$ for the $10-53 \mathrm{\mu m}$ fraction is approximately 3 -fold higher than the minimum cell quota of $0.5 \times 10^{-13}$ for a comparable size range of cells in culture (Shuter 1978). Since the ratio of maximum cell quota to minimum for nitrogen averages about 4 for cultures (Morel 1987), the measured cell quota seems reasonable and is not a likely source of error. The analytical blank also appeared to be quite constant (Fig. 2) and tests with differing numbers of cells from a single field population resulted in reasonable precision (7.7\%) given the small masses available for analysis. These potential errors, however, affect calculation of utilization of both $\mathrm{NH}_{4}{ }^{+}$ and $\mathrm{NO}_{3}{ }^{-}$equally, yet the values for use of $\mathrm{NO}_{3}{ }^{-}$were all lower than filtration, whereas $\mathrm{NH}_{4}{ }^{+}$values clustered nearer the value for the bulk particles. A closer correspondence should be achievable for nitrogen assimilation since Li (1994) reported that FCCS based measurement of primary production was $95 \%$ of that measured using traditional filtration.

\section{CONCLUSIONS}

Flow cytometry with cell sorting proved an effective tool to isolate phytoplankton from the diverse population of particles present in natural waters for studies of physiological responses. Removal of detritus, grazers and bacteria permitted proper attribution of nitrogenspecific uptake rates to phytoplankton and revealed variations due to cell size and nutrient preference. Analysis of cell quotas and $\mathrm{C}: \mathrm{N}$ ratios was also possible and provided additional evidence that the phytoplankton were growing rapidly. Absolute growth rates based on diel incubations were comparable to other estimates for coastal waters. The major limitation of FCCS for stable isotope studies is the time required to sort sufficient cells for isotopic and mass analysis. Future efforts should utilize concurrent additions of ${ }^{15} \mathrm{~N}$ and ${ }^{13} \mathrm{C}$ to test the assumptions of balanced growth by comparing $\mu_{\mathrm{N}}$ and $\mu_{\mathrm{C}}$. FCCS should also be useful to isolate different pigment classes of phytoplankton (Li 1994) or phytoplankton and their grazers or to further explore the relationship between growth or cell quota of various subpopulations to nutrient concentration and the utilization of different nitrogen sources.

Acknowledgements. This work was supported by grant NSFOCE8711737 and is BBSR contribution no. 1388. I thank Steve Wofsy for his encouragement and advice and Clarice Yentsch for opening this avenue of research to me. The field work succeeded due to the unstinting efforts and wisdom of Terry Cucci as he indoctrinated me in the intricacies of flow cytometry. Kjell Gundersen kindly conducted the CHN analyses and D. Hansell commented on the manuscript.

\section{LITERATURE CITED}

Banse K (1987) Clouds, deep chlorophyll maxima and the nutrient supply to the mixed layer of stratified water bodies. J Plankton Res 9:1031-1036

Bronk DA, Glibert PM (1993a) Application of a ${ }^{15} \mathrm{~N}$ tracer method to the study of dissolved organic nitrogen uptake during spring and summer in Chesapeake Bay. Mar Biol $115: 501-508$

Bronk DA, Glibert PM (1993b) Contrasting patterns of dis- 
solved organic nitrogen release by two size fractions of estuarine plankton during a period of rapid $\mathrm{NH}_{4}{ }^{+}$consumption and $\mathrm{NO}_{2}{ }_{2}^{-}$production. Mar Ecol Prog Ser 96:291-299

Burmaster DE (1979) The continous culture of phytoplankton: mathematical equivalence among three steady-state models. Am Nat 113:123-134

Chang J. Carpenter EJ (1991) Species-specific phytoplankton growth rates via diel DNA synthesis cycles 5. Application to natural populations in Long Island Sound. Mar Ecol Prog Ser 78:115-122

Chisholm SW (1992) Phytoplankton size. In: Falkowski PG, Woodhead AD (eds) Primary productivity and biogeochemical cycles in the sea. Plenum Press, New York, p $213-237$

Collos Y (1989) A linear model of external interactions during uptake of different forms of inorganic nitrogen by microalgae. J Plankton Res 11:521-533

Cuhel RL, Ortner PB, Lean DRS (1984) Night synthesis of protein by algae. Limnol Oceanogr 29:731-744

Cullen J, Stewart E, Renger E, Eppley RW, Winant CD (1983) Vertical motion of the thermocline, nitracline, and chlorophyll maximum layer in relation to currents on the Southern California shelf. J mar Res 41:239-262

DiTullio GR, Laws EA (1983) Estimates of phytoplankton $\mathrm{N}$ uptake based on ${ }^{14} \mathrm{CO}_{2}$ incorporation into protein. Limnol Oceanogr 28:177-185

Dortch Q (1990) The interaction between ammonium and nitrate uptake in phytoplankton. Mar Ecol Prog Ser 61. $183-201$

Dugdale RC, Goering JJ (1967) Uptake of new and regenerated forms of nitrogen in primary productivity. Limnol Oceanogr 12:196-206

Dugdale RC, Wilkerson FP (1986) The use of ${ }^{15} \mathrm{~N}$ to measure nitrogen uptake in eutrophic oceans; experimental considerations. Limnol Oceanogr 31:673-689

Eppley RW (1981) Relations between nutrient assimilation and growth in phytoplankton with a brief review of estimates of growth rate in the ocean. Can J Fish Aquat Sci 210:251-263

Fiedler R, Proksch G (1975) The determination of nitrogen-15 by emission and mass spectrometry in biochemical analysis: a review. Analyt chim Acta 78:1-62

French DP, Furnas MJ, Smayda TJ (1983) Diel changes in nitrite concentration in the chlorophyll maximum in the Gulf of Mexico. Deep Sea Res 30:702-722

Furnas MJ (1983) Nitrogen dynamics in lower Narragansett Bay, Rhode Island. I. Uptake by size-fractionated phytoplankton populations. J Plankton Res 5:657-676

Furnas MJ (1990) In situ growth rates of marine phytoplankton: approaches to measurement, community and species growth rates. J Plankton Res 12:1117-1151

Garside C (1991) Shift-up and nitrate kinetics of phytoplankton in upwelling systems. Limnol Oceanogr 36:1239-1244

Gieskes WWC, Kraay GW (1989) Estimating the carbon-specific growth rate of the major algal species groups in eastern Indonesian waters by ${ }^{14} \mathrm{C}$ labelling of taxon-specific carotenoids. Deep Sea Res 36:1127-1139

Glibert PM (1982) Regional studies of daily, seasonal and size fraction variability in ammonium remineralization. Mar Biol 70:209-222

Goericke R, Welschmeyer NA (1993) The chlorophylllabelling method: measuring specific rates of chlorophyll a synthesis in culture and in the open ocean. Limnol Oceanogr 38:80-95

Goldman JC, McCarthy JJ, Peavey DG (1979) Growth rate influence on the chemical composition of phytoplankton in oceanic waters. Nature 279:210-215
Goldman JC, Taylor CD, Glibert PM (1981) Nonlinear timecourse uptake of carbon and ammonium by marine phytoplankton. Mar Ecol Prog Ser 6:137-148

Goleb JA, Middleboe N (1968) Optical nitrogen-15 analysis of small nitrogen samples with a mixture of helium and xenon to sustain the discharge in an electrodeless tube Analytica chim Acta 43:229-234

Herman A, Platt T (1986) Primary production profiles in the ocean: estimation from a chlorophyll/light model. Oceanol Acta 9:31-40

Horrigan S, Hagström A, Azam F, Koike I (1984) Bacterioplankton growth in seawater may be nitrogen limited Trans Am geophys Union 65:921

Itturiaga R, Zsolnay A (1981) Differentiation between autoand heterotrophic activity: problems in the use of size fractionation and antibiotics. Botanica mar 24:399-404

Koike I, Holm-Hansen O, Biggs DC (1986) Inorganic nitrogen metabolism by Antarctic phytoplankton with special reference to ammonium cycling. Mar Ecol Prog Ser 30:105-116

Laws EA, Harrison WG, DiTullio GR (1985) A comparison of nitrogen assimilation rates based on ${ }^{15} \mathrm{~N}$ uptake and autotrophic protein synthesis. Deep Sea Res 32:85-95

Laws EA, Wong DCL (1978) Studies of carbon and nitrogen. metabolism by three marine phytoplankton species in nitrate-limited continuous culture. J Phycol 14:406-416

Lebouteiller A (1986) Environmental control of nitrate and ammonium uptake by phytoplankton in the equatorial Atlantic Ocean. Mar Ecol Prog Ser 30:1647-179

Lee C, Hedges JI, Wakeham SG, Zhu N (1992) Effectiveness of various treatments in retarding microbial activity in sediment trap material and their effects on the collection of swimmers. Limnol Oceanogr 37:117-130

Li WKW (1986) Experimental approaches to field measurements: methods and interpretation. In: Platt T, Li WKW (eds) Photosynthetic picoplankton. Can Bull Fish Aquat Sci 214:251-286

Li WKW (1994) Primary production of prochlorophytes, cyanobacteria, and eucaryotic ultraphytoplankton: measurements from flow cytometric sorting. Limnol Oceanogr 39:169-175

Lignell R (1992) Problems in filtration fractionation of C-14 primary productivity samples. Limnol Oceanogr 37: $172-178$

Lipschultz F (1984) Environmental factors affecting nitrogen cycling. PhD thesis, Harvard University, Cambridge

Lipschultz F (1993) Diode array spectrometer for nitrogen isotopic analysis. Appl Spectrosc 47:2093-2095

Lipschultz F (1994) Consumption of nitrate by Sargasso Sea phytoplankton: comparison of deep water, rain and inorganic sources. Trans Am geophys Union 75:39

Lipschultz F, Wofsy SC, Fox LE (1985) The effects of light and nutrients on rates of ammonium transformation in a eutrophic river. Mar Chem 16:329-341

Lund BA (1987) Mutual interference of ammonium, nitrate, and urea on uptake of ${ }^{15} \mathrm{~N}$ sources by the marine diatom Skeletonema costatum (Grev.) Cleve. J exp mar Biol Ecol 113:167-180

MacIsaac JJ (1978) Diel cycles of inorganic nitrogen uptake in a natural phytoplankton population dominated by Gonyaulax polyedra. Limnol Oceanogr 23:1-9

MacIsaac JJ, Dugdale RC (1969) The kinetics of nitrate and ammonia uptake by natural populations of marine phytoplankton. Deep Sea Res 16:45-57

MacIsaac JJ, Dugdale RC (1972) Interactions of light and inorganic nitrogen in controlling nitrogen uptake in the sea. Deep Sea Res 19:209-232

Malone TC (1980) Size-fractionated primary productivity of 
marine phytoplankton. In: Falkowski P G (ed) Primary productivity in the sea. Plenum Press, New York, $p$ $301-320$

Marra J, Bidigare RR, Dickey TD (1990) Nutrients and mixing, chlorophyll and phytoplankton growth. Deep Sea Res 37 : $127-143$

McCarthy JJ, Wynne D, Berman I (1982) The uptake of dissolved nutrogenous nutrients by Lake Kinneret (Israel) microplankton. Limnol Oceanogr 27:673-680

Morel FMM (1987) Kinetics of nutrient uptake and growth of phytoplankton. J Phycol 23:137-150

Nagata T (1986) Carbon and nitrogen content of natural planktonic bacteria. Appl environ Microbiol 52:28-32

Nelson DM, Conway HL (1979) Effects of the light regime on nutrient assimilation by phytoplankton in the Baja Califor. nia and northwest Africa upwelling systems. J mar Res 37: $301-318$

Olson RJ, SooHoo JB, Kiefer DA (1980) Steady-state growth of the marine diatom Thalassiosira pseudonana. Plant Physiol 66:383-389

Price NM, Andersen LF, Morel FMM (1991) Iron and nitrogen nutrition of equatorial Pacific plankton. Deep Sea Res 38 : $1361-1378$

Probyn TA (1985) Nitrogen uptake by size-fractionated phytoplankton populations in the southern Benguela upwelling system. Mar Ecol Prog Ser 22:249-258

Probyn TA, Waldron HN, James AG (1990) Size-fractionated measurcments of nitrogen uptake in aged upwelled waters: implication for pelagic food webs. Limnol Oceanogr 33:202-211

Redalje DG, Laws EA (1981) A new method for estimating phytoplankton growth rates and carbon biomass. Mar Biol 62:73-79

Rivkin RB, Phinney DA, Yentsch CM (1986) Effects of flow cytometric analysis and sorting on photosynthetic carbon uptake by phytoplankton in cultures and from natural populations. Appl environ Microbiol 52:935-938

Sakshaug E (1980) Problems in the methodology of studying phytoplankton. In: Morris I (ed) The physiological ecology of phytoplankton. Blackwell, London, p 57-91

Sakshaug E, Holm-Hansen O (1977) Chemical composition of Skeletonema costatum and Pavlova (Monochrysis)

This article was presented by D. Stoecker (Senior Editorial Advisor), Cambridge, Maryland, USA
Jutheri as a function of nitrate-, phosphate- and iron-limited growth J exp mar Biol Ecol 29:1-34

Shuter BJ (1978) Size dependence of phosphorus and nitrogen subsistence quotas in unicellular organisms. Limnol Oceanogr 23:1248-1255

Stockner JG, Klut ME, Cochlan WP (1990) Leaky filters: a warning to aquatic ecologists. Can J Fish Aquat Sci 47 : $16-23$

Suttle CA, Cochlan WP, Stockner JG (1991) Size-dependent ammonium and phosphate uptake, and N:P supply ratios in an oligotrophic lake. Can J Fish Aquat Sci 48: $1226-1234$

Taguchi S, Laws EA (1988) On the microparticles which pass through glass fiber filter type GF/F in coastal and open waters. J Plankton Res 10:999-1008

Ward BB, Kilpatrick KA, Renger EH, Eppley RW (1989) Biological nitrogen cycling in the nitracline. Limnol Oceanogr $34: 493-513$

Welschmeyer NA, Lorenzen CJ (1984) Carbon-14 labeling of phytoplankton carbon and chlorophyll a carbon: determination of specific growth rates. Limnol Oceanogr 29 135-145

Wheeler PA, Glibert PM, McCarthy JJ (1982) Ammonium uptake and incorporation by Chesapeake Bay phytoplankton: short term uptake kinetics. Limnol Oceanogr 27: $1113-1128$

Wheeler PA, Kirchman DI (1986) Utilization of inorganic and organic nitrogen by bacteria in marine systems. Limnol Oceanogr 31:998-1009

Wilkerson FP, Dugdale RC (1987) The use of large shipboard barrels and drifters to study the effects of coastal upwelling on phytoplankton dynamics. Limnol Oceanogr 32:368-382

Yentsch CM, Horan PK, Muirhead K, Dortch Q, Haugen E, Legendre L, Murphy LS, Perry MJ, Phinney DA, Pomponi SA, Spinrad RW, Wood M, Yentsch CS, Zahuranec BJ (1983) Flow cytometry and cell sorting: a technique for analysis and sorting of aquatic particles. Limnol Oceanogr 28: $1275-1280$

Yentsch CS (1983) A note on the fluorescence characteristics of particles that pass through glass-fiber filters. Limnol Oceanogr 28:597-599

Manuscript first received: June 15, 1994

Revised version accepted: February 13, 1995 